\title{
Goramy spermatozoa quality after sub-zero freezing: The role of coconut water as the cryoprotectant
}

\author{
ABINAWANTO״, PRAMITA EKA PUTRI \\ Department of Biology, Faculty of Mathematics and Natural Sciences, Universitas Indonesia, Depok 16424, West Java, Indonesia. Tel./Fax. +62-727- \\ 0163, `email: abinawanto@gmail.com
}

Manuscript received: 14 January 2017. Revision accepted: 5 May 2017.

\begin{abstract}
Abinawanto, Putri PE. 2017. Goramy spermatozoa quality after sub-zero freezing: The role of coconut water as the cryoprotectant. Cell Biol Dev 1: 1-5. The coconut water effect combined with $5 \%$ of glycerol for preserving goramy spermatozoa at -34 ${ }^{\circ} \mathrm{C}$ for 48 hours has been studied. The study's objective is to find the best combination among concentrations of coconut water on $0 \%$, $21 \%, 23 \%, 25 \%, 27 \%$, and $29 \%$, respectively, combined with $5 \%$ of glycerol for maintaining good spermatozoa motility, viability and minimizing spermatozoa abnormality. One part of semen/sperm was mixed with three parts of solvent $(5 \%$ glycerol + fish ringer + coconut water) and equilibrated at $4{ }^{\circ} \mathrm{C}$ for $45 \mathrm{~min}$. The diluted sperm were then frozen at $-34{ }^{\circ} \mathrm{C}$ for $48 \mathrm{~h}$. Finally, cryopreserved sperms were thawed at $30{ }^{\circ} \mathrm{C}$ for $3-5 \mathrm{~min}$. Spermatozoa quality was evaluated before and after sub-zero freezing. Based on the Kruskal-Wallis test, spermatozoa motility and viability were higher than control $(\mathrm{P}<0.05)$, while the spermatozoa abnormality was not significantly different compared to control $(\mathrm{P}>0.05)$. Twenty-five percent of coconut water combined with $5 \%$ of glycerol was the best combination for preserving spermatozoa motility $(80.36 \pm 1.54) \%$ and spermatozoa viability $(82 \pm 1.86) \%$, and also minimized spermatozoa abnormality $(10 \pm 1.03) \%$.
\end{abstract}

Keywords: Coconut water, cryoprotectant, Osphronemus goramy, spermatozoa quality, sub-zero freezing

\section{INTRODUCTION}

According to the Ministry of Maritime Affairs and Fisheries, Republic of Indonesia data, Indonesian fish consumption increased by 5\% in 2013 (KKP 2013). Osphronemus goramy (Lacepede 1801) is Indonesia's most popular and commercial freshwater fish (Saparinto 2008). Goramy fish production in Indonesia was about $280,079,000 \mathrm{~kg}$ in 2000 (Dunia Ikan 2008). However, nowadays, goramy fish is cultured conventionally because of the limited male and female parents. Therefore, they usually put male and female parents together in one pond for a long time, which will be caused inbreeding. Hence, the genetic materials' quality was reduced (Alam et al. 2002).

Cryopreservation is used to maintain genetic materials for a long period. According to Bozkurt (2005), cryopreservation is the ex-situ conservation effort to preserve genetic materials in sub-zero temperatures for a certain time. The genetic materials cryopreserved include spermatozoa, ovum, somatic cells, and embryo (Simione, 2003).

Cryoprotectants and extenders are two important solutions to protect cells from ice crystals during freezing (Muchlisin 2005). Based on Jamieson (1991), glycerol, methanol, and dimethyl sulphoxide (DMSO) are common intracellular cryoprotectants used for cryopreserved fish spermatozoa. On the other hand, milk, egg yolk, and sugar were used as extracellular cryoprotectants (Jamieson 1991).
According to Routray et al. (2007), the extender is also needed to support cells with additional nutrition and maintain osmotic pressure during cryopreservation. Saline solution and fish Ringer solution are two extenders usually used for fish spermatozoa cryopreservation (Muchlisin 2005).

The previous cryopreservation study has been reported related to the fish spermatozoa, such as in Barbonymus gonionotus, Java Barb (Abinawanto et al. 2013), Osphronemus goramy (Abinawanto et al. 2011, 2012a, 2012b), Osteochiius hasseltii (Sunarma et al. 2007), Cyprinus carpio (Akcay et al. 2004), tilapia's fish (Chao et al. 1987), rainbow trout (Stoss and Donaldson 1983), carp (Harvey 1983; Horvath et al. 2003; Withler 1982), and salmonid (Harvey et al. 1982).

Dimethyl Sulfoxide (DMSO) was used as the cryoprotectant during the cryopreservation of goramy spermatozoa for 24 hours (Abinawanto et al., 2011). Besides, sucrose (Abinawanto et al. 2012a) and skim milk (Abinawanto et al. 2012b) were also used as a cryoprotectant for goramy spermatozoa. However, the effect of coconut water in many variations of concentration combined with $5 \%$ of glycerol on the spermatozoa quality of goramy was still unknown. Accordingly, the aim of the study was to find the suitable concentration of coconut water among $0 \%, 21 \%, 23 \%, 25 \%, 27 \%$, or $29 \%$ in preserving spermatozoa motility and viability and in reducing the spermatozoa abnormality during cryopreservation. 


\section{MATERIALS AND METHODS}

\section{Preparation of fish}

Fifteen mature males of Osphronemus goramy were brought from the private commercial hatchery, ParungBogor, West Java, Indonesia. All fishes were acclimatized for $14 \mathrm{~d}$ in a one-4,000-L square concrete cement pond until they attained 2.5-3.5 $\mathrm{kg}$ in the indoor Aquatic Biology laboratory, Biology Department, Faculty of Mathematics and Natural Sciences, Universitas Indonesia, Depok, West Java Province. The fishes were grouped into 6 fishes and were stocked in a 7-square concrete cement fish pond $(1,000-\mathrm{L})$. The fish pond was equipped with a closed recirculation system and a black plastic mesh lid to minimize disturbances and prevent fish from jumping out. Six experimental groups based on coconut water concentration were assigned four replications in a completely randomized design (Table 1). Fishes were fed with the commercial diet and leaf of Allocasia macrorrhiza two times daily ad libitum at 08:00 and 17:00.

\section{Fish ringer preparation}

Fish ringer solution was prepared according to the method of Ginzburg (1972). First, a fish ringer stock solution was prepared by dissolving $3.25 \mathrm{~g} \mathrm{NaCl}, 0.125 \mathrm{~g}$ $\mathrm{KCl}, 0.175 \mathrm{~g} \mathrm{CaCl}_{2} .2 \mathrm{H}_{2} \mathrm{O}$, and $0.1 \mathrm{~g} \mathrm{NaHCO}_{3}$ with aquabidest up to $500 \mathrm{~mL}$. The extender fish ringer solution was then kept at $4{ }^{\circ} \mathrm{C}$.

\section{Activator solution preparation}

The activator solution was prepared based on the method of Perchec et al. (1995) by diluting $45 \mathrm{mM} \mathrm{NaCl}, 5$ $\mathrm{mM} \mathrm{KCl}$, and $30 \mathrm{mM}$ Tris with aquabidest up to $100 \mathrm{~mL}$.

\section{5\% Eosin-Y solution preparation}

The $0.5 \%$ of Eosin-Y solution was prepared according to the method of WHO ( 2010) by diluting $0.5 \mathrm{~g}$ of the Eosin- $\mathrm{Y}$ with aquabidest up to $100 \mathrm{~mL}$.

\subsection{M of Phosphate buffer solution pH 6.8 preparation}

The phosphate buffer solution was prepared by dissolving $5.34 \mathrm{~g} \mathrm{Na}_{2} \mathrm{HPO}_{4} .2 \mathrm{H}_{2} \mathrm{O}$ with aquabidest up to $200 \mathrm{mLl}$, and by dissolving $4.08 \mathrm{~g} \mathrm{KH}_{2} \mathrm{PO}_{4}$ with aquabidest up to $200 \mathrm{mLl}$. $\mathrm{Na}_{2} \mathrm{HPO}_{4} .2 \mathrm{H}_{2} \mathrm{O}$ solution was then added to $\mathrm{KH}_{2} \mathrm{PO}_{4}$ solution until the $\mathrm{pH}$ reached 6,8. The Phosphate buffer solution was then kept at $4{ }^{\circ} \mathrm{C}$.

\section{Giemsa solution preparation}

The Giemsa solution was prepared based on WHO ( 2010) by diluting one part of the Giemsa stock solution and 10 parts of the phosphate buffer solution at $\mathrm{pH}$ 6.8. The mixed solution was then filtered by Whatman filter paper number one.

\section{Collection of the ejaculated sperm/semen}

The sperm was collected by hand stripping 8-10 hours after being injected intra-muscularly with GnRH-analog (Ovaprim Syndel) at a single dose of $0.2 \mathrm{ml} / \mathrm{kg}$ body weight according to the modification method of Sunarma et al. (2007) and was put in $1.5 \mathrm{~mL}$ of cryotube.
Table 1. Composition of Semen/sperm, Fish ringer, Coconut Water $(\mathrm{CW})$, and glycerol $(\mathrm{G})$ of the experimental group

\begin{tabular}{lcccccc}
\hline & \multicolumn{7}{c}{ Experimental group } \\
\cline { 2 - 7 } Composition & $\mathbf{C}$ & $\begin{array}{l}\mathbf{2 1 \%} \\
\text { CW }\end{array}$ & $\begin{array}{c}\mathbf{2 3 \%} \\
\mathbf{C W}\end{array}$ & $\mathbf{2 5 \%}$ & $\mathbf{2 7 \%}$ & $\mathbf{2 9 \%}$ \\
\hline $\begin{array}{l}\text { Semen/sperm } \\
(\mu \mathrm{L})\end{array}$ & 50 & 50 & 50 & 50 & 50 & 50 \\
$\begin{array}{l}\text { Fish finger } \\
\text { solution }(\mu \mathrm{L})\end{array}$ & 140 & 98 & 94 & 90 & 86 & 82 \\
$\begin{array}{l}\text { Coconut } \\
\text { water/ CW }\end{array}$ & 0 & 42 & 46 & 50 & 54 & 58 \\
$(\mu \mathrm{L})$ & & & & & & \\
$\begin{array}{l}5 \% \text { glycerol/G } \\
(\mu \mathrm{L})\end{array}$ & 10 & 10 & 10 & 10 & 10 & 10 \\
\hline $\begin{array}{l}\text { Note: } * \mathrm{C}=\text { control group }(0 \% \mathrm{CW}) ; * * 21 \% \mathrm{CW}, 23 \% \mathrm{CW}, 25 \% \\
\mathrm{CW}, 27 \% \mathrm{CW}, 29 \% \mathrm{CW}=\text { treatment group }\end{array}$ &
\end{tabular}

\section{Semen/sperm dilution}

According to Akcay (2004), the ratio between the ejaculated semen/sperm and the solvent was 1:3. The sperm was added to the solvent solution in the cryotube. The composition of each component of the solvent solution and the ejaculated sperm is seen in Table 1 .

\section{Semen/sperm equilibration}

The diluted sperm was then equilibrated at $4{ }^{\circ} \mathrm{C}$ for 45 minutes (Akcay et al., 2004; Bozkurt et al., 2005).

\section{Semen/sperm freezing}

The diluted sperm was frozen at $-34^{\circ} \mathrm{C}$ for $48 \mathrm{~h}$ (Huang et al. 2004).

\section{Semen/sperm thawing}

The frozen sperm was incubated at $30^{\circ} \mathrm{C}$ for $3-5 \mathrm{~min}$. (Akcay et al. 2004 and Bozkurt et al. 2005).

\section{Semen/sperm evaluation and spermatozoa analysis}

Visual observation was carried out on the fresh semen/sperm color, and the cryotube with a scale measured sperm volume. The standardized $\mathrm{pH}$ paper ( $\mathrm{pH}$ range 5-10) measured sperm/semen $\mathrm{pH}$. The spermatozoa viability, abnormality, and motility were observed under a trinocular microscope (Boeco) equipped with the digital eyepiece camera (MDCE-5a). This microscope was also connected to the computer equipped with image driving software (Scopephoto 2.0.4). The Rurangwa et al. (2004) method was used to analyze the spermatozoa motility, whereas the spermatozoa viability and motility were analyzed by Salisbury and Van De Mark method (1985).

\section{Data analysis}

All data were analyzed by Kruskal-Wallis and Dunnet's multiple comparison test (Zar 1974) using a statistic program of SPSS version 13 for Windows. All probability values were set at a 0.05 level of significance. 


\section{RESULTS AND DISCUSSION}

\section{Results}

Fresh semen (FS) was milky white, $\mathrm{pH} 8.06 \pm 0.05$, and $0.57 \pm 0.10 \mathrm{~mL}$ of volume per ejaculate (Table 2 ).

Figure 1 showed that non-viable spermatozoa showed red on the sperm head (A), while the viable spermatozoa showed green color on the sperm head (B). Both viable and non-viable spermatozoa were found in all treatment groups and control. However, the percentage of spermatozoa viability was quantitatively different, either among treatment groups or between control and treatment groups. Both normal and abnormal spermatozoa morphologically were found in all treatment groups and control (Figure 2). However, the percentage of spermatozoa normal and abnormal were different among treatment groups or between control and treatment groups. Table 3 shows the percentage of spermatozoa abnormality, viability, and motility two days after sub-zero freezing.

The percentage of spermatozoa motiliy after freezing in control; and in various coconut water concentration of $21 \%, 23 \%, 25 \%, 27 \%$, and $29 \%$, were: $(71.42 \pm 4.01) \%$, $(72.22 \pm 2.96) \%, \quad(77.39 \pm 2.26) \%, \quad(80.36 \pm 1.54) \%$ $(77.13 \pm 2.59) \%$, and $(74.09 \pm 1.98) \%$, respectively (Table 3$)$. The spermatozoa viability in control; and in various coconut water concentration of $21 \%, 23 \%, 25 \%, 27 \%$, and $29 \%$, two days after sub-zero freezing, were: $(72 \pm 3.42) \%$, $(75 \pm 3.36) \%,(79 \pm 2.22) \%,(82 \pm 1.86) \%,(80 \pm 1.47) \%$, and $(77 \pm 1.96) \%$, respectively (Table 3 ). On the other hand, the spermatozoa abnormality after freezing, in control; and in various coconut water concentration of $21 \%, 23 \%, 25 \%$, $27 \%$, and $29 \%$, were: $(11 \pm 1.83) \%, \quad(11 \pm 1.41) \%$, $(12 \pm 1.04) \%,(10 \pm 1.03) \%,(11 \pm 0.83) \%$, and $(11 \pm 0.75) \%$, respectively (Table 3 ).

Based on the Kruskal-Wallis test, there was a significant effect $(\mathrm{P}<0.05)$ of various concentrations of coconut water on spermatozoa viability and motility, respectively, to days after sub-zero freezing. On the other hand, there was no significant effect of coconut water on reducing spermatozoa abnormality $(\mathrm{P}>0.05)$ compared to the control (Table 3). According to the Dunnet test, 25\% coconut water concentration showed the highest percentage of spermatozoa viability $(82 \pm 1.86) \%$ and motility $(80.36 \pm 1.54) \%$, respectively.

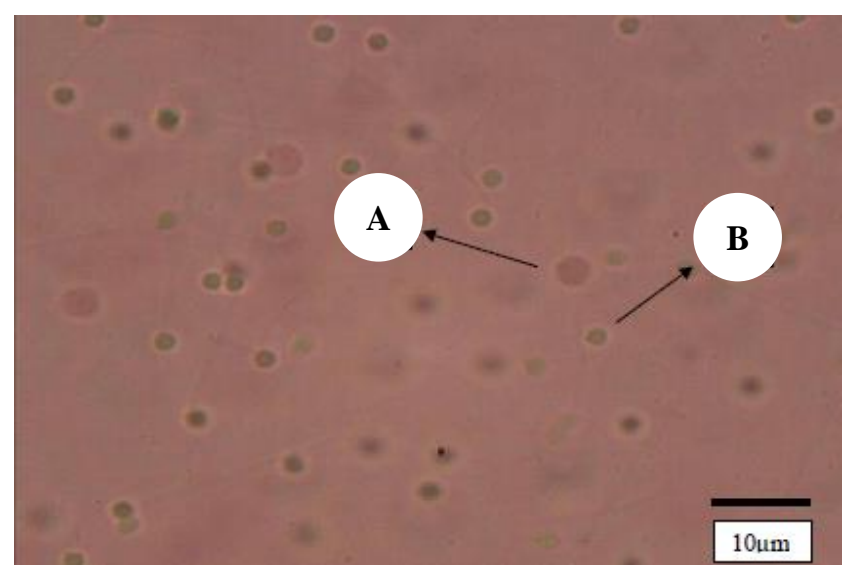

Figure 1. Spermatozoa non-viable (A); spermatozoa viable (B); $10 \times 40162 \times 95 \mathrm{~mm}(96 \times 96 \mathrm{DPI})$

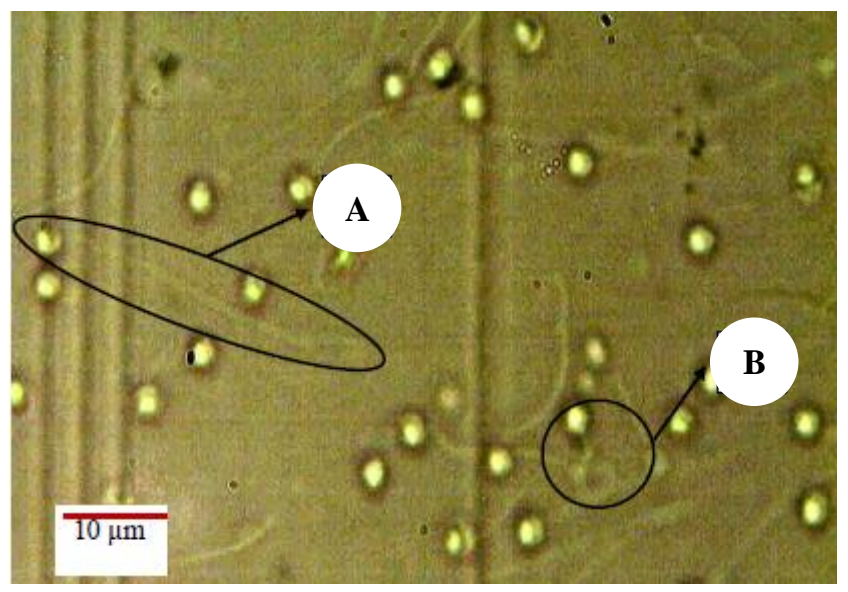

Figure 2. Normal spermatozoa (A); Round tail spermatozoa (B); $10 \times 40162 \times 204 \mathrm{~mm}^{2}(96 \times 96 \mathrm{DPI})$

Table 2. Fresh semen/sperm evaluation and spermatozoa analyses of goramy spermatozoa before freezing

\begin{tabular}{lccccc}
\hline Parameter & Color & Volume & Parameter & Color & Volume \\
\hline Semen/sperm & Milky white & $0.57 \pm 0.10$ & $8.06 \pm 0.05$ & $84 \pm 3.16$ & $13 \pm 0.63$ \\
\hline
\end{tabular}

Note: Values are means \pm SD of four replicates

Table 3. The percentage of the spermatozoa abnormality, viability, and motility of goramy 48 hours after sub-zero freezing

\begin{tabular}{|c|c|c|c|c|c|c|}
\hline \multirow{2}{*}{ Parameter } & \multicolumn{6}{|c|}{ Experimental group } \\
\hline & $\mathbf{C}$ & $21 \% \mathrm{CW}$ & $23 \% \mathrm{CW}$ & $25 \% \mathrm{CW}$ & $27 \% \mathrm{CW}$ & $29 \% \mathrm{CW}$ \\
\hline Viability (\%) & $72 \pm 3.42^{\mathrm{a}}$ & $75 \pm 3.36^{b}$ & $79 \pm 2.22^{\mathrm{bc}}$ & $82 \pm 1.86^{c}$ & $80 \pm 1.47^{\mathrm{bc}}$ & $77 \pm 1.96^{\mathrm{bc}}$ \\
\hline Abnormality $(\%)$ & $11 \pm 1.83^{\mathrm{a}}$ & $11 \pm 1.41^{\mathrm{a}}$ & $12 \pm 1.04^{\mathrm{a}}$ & $10 \pm 1.03^{\mathrm{a}}$ & $11 \pm 0.83^{\mathrm{a}}$ & $11 \pm 0.75^{\mathrm{a}}$ \\
\hline Motility (\%) & $71.42 \pm 4.01^{\mathrm{a}}$ & $72.22 \pm 2.96^{\mathrm{a}}$ & $77.39 \pm 2.26^{\mathrm{bc}}$ & $80.36 \pm 1.54^{\mathrm{b}}$ & $77.13 \pm 2.59^{c}$ & $74.09 \pm 1.98^{c}$ \\
\hline
\end{tabular}

Note: Values are means \pm SD of four replicates. Mean values having the same superscript are not significantly different $(\mathrm{p}>0.05)$ 


\section{Discussion}

The concentration of $25 \%$ coconut water was shown to have the highest percentage of spermatozoa motility $(80.36 \pm 1.54) \%$, two days after sub-zero freezing. This finding was similar to the previous study (Horvarth and Urbanyi, 2000) when they preserved spermatozoa of Clarias gariepinus. On the other hand, post thaw motility in this study was lowered compared our previous study (80.98\%; Abinawanto et al. 2012b; 96.10\%; Abinawanto et al. 2013). However, post-thaw motility in this study was higher than Brachydanio rerio (51\%; Harvey et al. 1982), Oreochromis mossambicus (70\%; Harvey 1983), tilapia's fish (40\%; Chao et al. 1987), Cyprinus carpio (55\%; Akcay et al. 2004), Osteochiius hasseltii (63.33\%; Sunarma et al. 2007), and Osphronemus goramy (68.58\%; Abinawanto et al. 2011). Post-thaw viability in the treatment group of 5\% glycerol was $75.5 \pm 5.43 \%$, although it was not statistically significantly different compared with other treatment groups and control. However, this finding was higher than previously reported in spermatozoa of Mystus nemurus (60\%; Muchlisin et al. 2004), Cyprinus carpio (20\%; Withler 1982; 58\%; Horton and Otto 1976), and Osphronemus goramy (63.5\%; Abinawanto et al. 2011). On the other hand, post-thaw viability in this study was lower than in our previous work in Barbonymus gonionotus spermatozoa (77.25\%; Abinawanto et al. 2009; 85.50; Abinawanto et al. 2013). The effect of 5\% of glycerol can decline the post-thaw abnormality $(14.83 \pm 2.79) \%$, better than another treatment group of glycerol concentration and control group, although those results were not significantly different statistically. Our previous study showed a higher spermatozoa abnormality (29\%; Abinawanto et al. 2011) when using the combination of $13 \%$ DMSO $+189 \mathrm{M}$ extender. Post-thaw abnormality in Barbonymus gonionotus spermatozoa was higher $(45 \%)$ when preserved in the combination of $6 \%$ glucose $+10 \%$ methanol (Abinawanto et al. 2009). However, the post-thaw abnormality showed nearly similar (14\%) when the spermatozoa of Barbonymus gonionotus were protected by the combination of $13 \%$ of egg yolk $+10 \%$ of methanol (Abinawanto et al. 2013).

Either treatment groups or control was visually shown as viable spermatozoa, motile spermatozoa, and abnormal spermatozoa. However, the percentage of spermatozoa viability, motility, and abnormality differed among treatment groups or between control and treatment groups. Therefore, the optimum condition of the treatment group (percentage of glycerol) was shown by the lowest percentage of spermatozoa abnormality (by reduced percentage of spermatozoa abnormality) after sub-zero freezing for two days. Furthermore, the highest percentage of viability or motility of spermatozoa among the treatment groups or between control and treatment groups two days after sub-zero freezing is also an indicator of the optimum condition of a percentage of glycerol as the cryoprotectant.

The data obtained in the present study indicate that $25 \%$ coconut water combined with $5 \%$ glycerol showed the highest spermatozoa motility and spermatozoa viability and reduced spermatozoa abnormality two days after sub-zero freezing.

\section{ACKNOWLEDGEMENTS}

We would like to thank Directorate General for Higher Education, Department of National Education, the Republic of Indonesia, that funded this study through the University of Indonesia Competitive Research Grant No. 240AT/DRPM-UI/N1.4/2008 for the financial support.

\section{REFERENCES}

Abinawanto A, Fadhillah, Lestari R. 2009. The effect of glucose in various concentrations on sperm quality of Barbonymus gonionotus (Bleeker, 1850) 24 hours post-cryopreservation. J Rep Dev. 55 Suppl. DOI: $10.14882 /$ jrds. 102.0.224.0

Abinawanto, Bayu MD, Lestari R., Sunarma A. 2011. Spermatozoa quality of goramy fish, Osphronemus goramy Lacepede, 1801 twenty four hours post-cryopreservation: The role of dimethyl sulfoxide (DMSO) as a cryoprotectant. Biota 16:10-15.

Abinawanto, Anindita I, Lestari R. 2012b. Cryopreservation of spermatozoa of Osphronemus goramy fish using skim milk. Inter $\mathbf{J}$ Eng Innov Tech 2 (5):62-64.

Abinawanto, Nurman K, Lestari R. 2012a. The effect of sucrose on sperm quality of goramy fish, Osphronemus goramy Lacepede, 1801 two days post-cryopreservation. J Agric Sci Tech B2: 204-207.

Abinawanto, Rahayu S, Lestari R. 2013. Cryopreservation of Java Barb (Barbonymus gonionotus) spermatozoa using egg yolk as a cryoprotectant. Global Vet 10 (3): 318-321.

Akcay E, Bozkurt Y, Secer S, Tekin N. 2004. Cryopreservation of mirror carp semen. Turkey J Vet Animal Sci 28:837-843.

Alam MA, Akanda MSA, Alam S. 2002. Comparison of genetic variability between a hatchery and a river population of Rohu (Labeo rohita) by allozyme electrophoresis. Pakistan J Biol Sci 5 (9):959961.

Bozkurt Y, Akcay E, Tekin N, Secer S. 2005. Effect of freezing techniques, extenders, and cryoprotectants on the fertilization rate of frozen rainbow trout (Oncorhyncus mykiss) sperm. Israeli J AquaBamidgeh 57: 1-6.

Chao NH, Chao WC, Liu KC, Liao IC. 1987 The properties of tilapia sperm and its cryopreservation. J Fish Biol 30 (2):107-118.

Christensen JM, Tiersch TR. 2005. Cryopreservation of channel catfish sperm: effects of Cryoprotectant exposure time, cooling rate, thawing conditions, and male-to-male variation. Theriogenology 63 (8): 21032112.

Fickle J, Asja W, Arne L. 2007. Semen cryopreservation and the conservation of endangered species. Europ J Wild Res 53 (2): 81-89.

Ginzburg AS. 1972. Fertilization in fishes and the problem of polyspermy. Israel Program for Scientific Translation, Jerusalem.

Harvey B, Kelley NR, Ashwood-Smith M.J. 1982 Cryopreservation of zebrafish spermatozoa using methanol. Canada J Zool 60 (8): 1867 1870 .

Harvey B. 1983 Cryopreservation of Sarotherodon mossambicus spermatozoa. Aquaculture 32: 313-320.

Horton HF, OttoAG. 1976 Cryopreservation of fish spermatozoa and ova. J Fish Res Board Canadian 32 (3-4): 995-1000.

Horvath A, Miskolczi E., Urbanyi B. 2003. Cryopreservation of common carp sperm. Aqua Liv Res 16: 457-460.

Horvath A. Urbanyi B. 2000. The effect of cryoprotectans on the motility and fertilizing capacity of cryopreserved African catfish, Clarias gariepinus (Burchell 1882) sperm. Aqua Res 31: 317-324.

Huang C, Dong Q, Walter RB, Tiersch TR. 2004. Sperm cryopreservation of green swordtail Xiphophorus helleri, a fish internal fertilization. Cryobiology 48 (3): 295-308.

Kang KH, Kho KH, Chen ZT, Kim JM., Zhang ZF. 2004. Cryopreservation of file fish (Thamnaconus septentrionalis Gunther, 1877) sperm. Aquacult Res 35: 1429-1433.

Kusuda S, Koide N, Kawamula H., Teranishi JT, Nakajima I., Yamaha E, Arai K., Ohta H. 2005 Cryopreservation diluents for spermatozoa of Sakhalin taimen Hucho perryi. Fish Sci 71: 293-298.

Muchlisin ZA, Hashim R., Chong ASC. 2004. Preliminary study on cryopreservation of tropical bagrid catfish (Mystus nemurus) 
spermatozoa: the effect of extender and cryoprotectant on the motility after short-term storage. Theriogenology 62 (1-2): 25-34..

Park C, Chapman FA.. 2005. An extender solution for the short-term storage of Sturgeon semen. North Amer J Aqua 67 (1): 52-57.

Perchec G, Jeulin C, Cosson J, Andre F, Billard R. 1995. Relationship between sperm ATP content and motility of carp spermatozoa. J Cell Sci 108: 747-753.

Rurangwa E, Kime DE, Ollevier F, Nash JP. 2004. Review article: The measurement of sperm motility and factors affecting sperm quality in cultured fish. Aquaculture 234: 1-28.

Salisbury GW, Van De Mark NL. 1985. Reproductive physiology and induced breeding. W.H. Freeman and Co., San Francisco

Sunarma A., Hastuti DW, Sistina Y. 2007 The use of honey extender combined with different cryoprotectants on the preservation of sperm nilem fish (Indonesian Sharkminnow, Osteochiius hasselti
Valenciennes, 1842). Konferensi Aquaculture Indonesia 2007, Surabaya, 5-7 Juni, 2007. Masyarakat Akuakultur Indonesia, Surabaya [Indonesian]

Urbanyi B, Horvarth A, Varga Z, Horvarth L. 1999. Effect of extenders on sperm cryopreservation of African catfish, Clarias gariepinus (Burchell 1882). Aqua Res 30: 145-151.

WHO [World Health Organization]. 2010. WHO laboratory manual for the examination of human semen and spermcervical mucus interaction. 5th ed. World Health Organization, Geneva, Switzerland

Withler FC. 1982 Cryopreservation of spermatozoa of some freshwater fishes cultured in South and Southeast Asia. Aquaculture 26 (3-4): 395-398.

Zar JH. 1974. Biostatiscal analysis. Prentice-Hall Inc. London. 